\title{
Kinerja Pelayanan Dan Rehabilitasi Kesejahteraan Sosial Di Dinas Sosial Kota Bekasi
}

\author{
${ }^{1}$ Fikri Emsa, ${ }^{2}$ Zaenuri Khairul Anwar
}

\author{
${ }^{1}$ Jurusan Manajemen Rumah Sakit Program Pascasarjasana Universitas Pasundan; fikriemsa.s@gmail.com \\ ${ }^{2}$ Administrasi Publik Fakultas Ilmu Sosial dan Ilmu Politik UIN Sunan Gunung Djati Bandung; \\ zayn1501@gmail.com
}

\begin{abstract}
This research is motivated by not achieving the performance targets of the City Social Services so that this study aims to analyze the performance of social welfare services and rehabilitation programs in the Bekasi City Social Service. The research method used in this study is a qualitative approach to the type of descriptive research. In conducting data collection, this study uses interview, observation, and documentation techniques. Then for the data analysis technique that is done is with three different types of activities consisting of reduction, data models, and drawing conclusions. Based on the results of the study, it shows that the performance of the Bekasi City Social Service is quite good but it is still considered to be less than optimal and must be improved again. There are several factors that affect the sub-optimal performance of the Bekasi City Social Service in carrying out social welfare rehabilitation and service programs. To achieve optimal results, it is necessary to have a review of the readiness of the resources (budget, professional workforce, and other materials) in the Bekasi City Social Service.
\end{abstract}

Keywords: Performance, Public Service, Local Government, Social Welfare.

\section{Pendahuluan}

Sejalan dengan perkembangan masalah dan kebutuhan para penyandang disabilitas dan kaum lanjut usia, oleh sebab itu maka sudah semestinya perlu adanya suatu upaya yang dapat memberikan serta menjamin perlindungan yang layak bagi mereka untuk dapat mewujudkan serta memelihara taraf kesejahteraan sosialnya agar tidak lagi terjadi hal-hal yang tidak diinginkan. Salah satu upaya untuk perlindungan dan jaminan kesejahteraan bagi penyandang disabilitas dan kaum lanjut usia, Pemerintah Kota Bekasi bersama Dinas Sosial Kota Bekasi memberikan perhatian lebih terhadap para penyandang disabilitas dan lanjut usia melalui Program Pelayanan dan Rehabilitasi Kesejahteraan Sosial (PPRKS) dengan cara memberikan sembako yang pelaksanaannya berlandaskan pada Peraturan Walikota Nomor 73 Tahun 2016 Tentang Tugas, Fungsi, dan Tata Kerja Dinas Sosial Kota Bekasi.

Tujuan dari pemberian sembako bagi penyandang diasbilitas dan lanjut usia adalah untuk memenuhi kebutuhan dasar mereka yang merupakan salah cara untuk meningkatkan kesejahteraan bagi penyandang disabilitas dan lanjut usia. Meningkatnya Pelayanan Kesejahteraan Sosial merupakan salah satu indikator dari program Pelayanan dan Rehabilitasi Kesejahteraan Sosial (PPRKS) yang sasarannya merupakan Penyandang Disabilitas Fisik dan Mental serta kaum lanjut usia. Dilansir dari Bidang Perencanaan Dinas Sosial Kota Bekasi Pada tahun 2017 Dinas Sosial Kota Bekasi sebagai unit kerja sekaligus unsur pelaksana otonomi daerah di bidang sosial menargetkan program tersebut dengan presentase total $44 \%$ atau 1.890 orang dari 4.297 jumlah keseluruhan dari para penyandang disabilitas baik fisik maupun mental serta kaum lanjut usia, namun realisasi program tersebut hanya $25 \%$ atau 
1.068 orang. Fenoma tersebut dapat dilihat dari tabel target dan realisasi program pelayanan dan rehabilitasi sosial yang disajikan di bawah ini:

\section{Tabel 1.1}

\section{Target serta Realisasi dari Program Pelayanan dan Rehabilitasi Sosial}

\begin{tabular}{|l|l|c|l|l|}
\hline Program & $\begin{array}{l}\text { Indikator } \\
\text { Sasaran }\end{array}$ & Target & $\begin{array}{l}\text { Realisa } \\
\text { si }\end{array}$ & $\begin{array}{l}\text { Capaian } \\
\text { Kinerja }\end{array}$ \\
\hline $\begin{array}{l}\text { Program Pelayanan } \\
\text { dan Rehabilitasi } \\
\text { Kesejahteraan Sosial }\end{array}$ & Lanjut Usia & 44 & 25 & 56 \\
\hline
\end{tabular}

Sumber: Bidang Perencanaan Dinas Sosial Kota Bekasi Tahun 2017

Pada tabel di atas Dinas Sosial Kota Bekasi menetapkan target program pelayanan dan rehabilitasi sosial sebesar $44 \%$ namun program tersebut hanya terealisasikan sebesar $25 \%$. Diketahui bahwa jumlah jiwa penyandang disabilitas dan lanjut usia yang tidak potensial menerima bantuan sosial di Kota Bekasi sebanyak 4. 297 jiwa. Adapun jumlah jiwa yang ditargetkan sebanyak 1. 890 jiwa, sedangkan yang terealisasikan hanya 1. 068 jiwa. Program tersebut didukung dengan adanya beberapa kegiatan yaitu:

\section{Tabel 1.2}

\section{Program Pelayanan dan Rehabilitasi untuk Kesejahteraan Sosial}

\begin{tabular}{|l|l|l|}
\hline Program & Sasaran & Kegiatan \\
\hline $\begin{array}{l}\text { Program Pelayanan dan } \\
\text { Rehabilitasi } \\
\text { Kesejahteraan Sosial }\end{array}$ & $\begin{array}{l}\text { Lanjut usia dan } \\
\text { penyandang } \\
\text { disabilitas fisik } \\
\text { serta mental }\end{array}$ & $\begin{array}{l}\text { Pemberian Sembako kepada Cacat } \\
\text { fisik serta mental di Panti Sosial }\end{array}$ \\
\cline { 3 - 3 } & $\begin{array}{l}\text { Pemberian Sembako dan Pelatihan } \\
\text { Kepada Lansia }\end{array}$ \\
\cline { 3 - 4 } & $\begin{array}{l}\text { Penguatan Kelembagaan Lanjut Usia } \\
\text { Indonesia (LLI) }\end{array}$ \\
\hline
\end{tabular}

Sumber: Bidang Perencanaan Dinas Sosial Kota Bekasi Tahun 2017

Diketahui bahwa program pelayanan dan rehabilitasi kesejahteraan sosial belum terlaksana secara optimal. Hal tersebut ditandai dengan tidak ada capaian yang nyata dari realisasi itu sendiri terhadap target yang sudah ditentukan. Dimana pada tabel 1.3 program tersebut menargetkan $44 \%$ atau 1.890 orang sedangkan realisasi program tersebut hanya $25 \%$ atau 1.068 orang. Menurut data di atas penulis menemukan adanya fenomena-fenomena didalam menjalankan program Pelayanan dan Rehabilitasi Kesejahteraan Sosial sebagai berikut:

1. Belum meratanya penerima bantuan bagi penyandang disabilitas dan lanjut usia. Hal tersebut terlihat pada targetan dengan capaian program.

2. Kurangnya pengawasan dalam menjalankan kegiatan sehingga masih banyak penyandang disabilitas dan lanjut usia yang belum menerima bantuan dari program tersebut. 
3. Perlu dilakukannya suatu pengukuran atau penghitungan skala kinerja guna meninjau kembali sejauh mana skala keberhasilan dari organisasi dalam menjalankan tugas dan program-program yang telah direncanakan sehingga dapat diambil suatu tindak nyata untuk mengatasi masalah tersebut.

Menurut Mahsun (2016:25) kinerja merupakan suatu gambaran dari tingkat pencapaian atau pelaksanaan dari suatu kebijakan, program maupun kegiatan yang ingin diwujudkan dalam rangka perwujudan tujuan, sasaran, visi, serta misi nyata dari suatu organisasi maupun instansi tertentu. Sedangkan definisi dari kinerja sendiri menurut Lembaga Administrasi Negara atau LAN (dalam Umam, 2012: 355) didefinisikan sebagai suatu prestasi dalam bekerja, pelaksanaan suatu pekerjaan, pencapaian yang konkrit dari suatu tindakan kerja/ hasil nyata dari tindakan kerja ataupun penampilan dari suatu kinerja yang diterjemahkan dari kata performance.

Dari berbagai definisi kinerja yang telah dijabarkan di atas, maka peneliti mengambil suatu benang merah bahwa kinerja dapat didefinisikan sebagai suatu capaian yang nyata serta konkrit dari suatu organisasi dalam rangka pelaksanaan serta perwujudan dari seluruh kebijakan, kegiatan, serta program guna tercapainya suatu tujuan atau visi yang telah ditentukan oleh organisasi tersebut. Sedangkan Mahsun (2016:77) mengemukakan bahwa yang menjadi indikator dari kinerja setiap badan pemerintah itu meliputi seluruh indikator, yaitu mulai dari masukan (input), keluaran (output), hasil (outcome), manfaat (Benefit), hingga dampak (impact). Adapun yang menjadi penjelasan atau uraian mendetail mengenai indikator tersebut ialah:

a. Indikator masukan (input) meliputi seluruh hal yang dibutuhkan untuk pelaksaaan kegiatan yang akan diselenggarakan agar dapat berjalan dengan baik serta dapat menghasilkan keluaran yang baik pula. Indikator masukan mengukur sejumlah sumber daya yang meliputi sumber daya anggaran (dana), sumber daya manusia (SDM), material, peralatan, serta masukan lain, yang digunakan untuk melaksanakan program yang akan dilaksanakan tersebut agar berjalan dengan baik sesuai dengan harapan.

b. Indikator proses (Process) merupakan tindakan pengukuran dari suatu kegiatan tertentu mulai dari segi kecepatan, ketepatan, maupun tingkat akurasi yang tinggi dari pelaksanaan kegiatan tersebut.

c. Indikator keluaran (output) merupakan sesuatu atau hal dari setiap kegiatan yang dilaksanakan yang kemudian diharapkan adanya suatu keluaran yang langsung dapat dicapai dari suatu kegiatan yang dapat berupa baik fisik maupun non-fisik.

d. Indikator Hasil (Outcomes) merupakan segala sesuatu atau hal yang merupakan cerminan dari fungsi keluaran yang telah dujelaskan sebelumnya yang fungsinya untuk keluaran kegiatan yang dilaksanakan pada jangka menengah.

e. Indikator Manfaat (Benefit) merupakan sesuatu atau hal yang selalu relevan dengan tujuan akhir dari setiap pelaksanaan kegiatan yang diselenggarakan oleh setiap organisasi.

f. Indikator Dampak (Impact) merupakan suatu pengaruh yang dihasilkan dari setiap hasil dari kegiatan yang diselenggarakan oleh organisasi yang meliputi hal yang baik, buruk, positif hingga negatif yang akan dirasakan oleh masyarakat luas pada umumnya.

Berdasarkan uraian di atas maka penulis tertarik akan melakukan penelitian yang bertujuan untuk menganalisis kinerja program pelayanan dan rehabilitasi kesejahteraan sosial di Dinas Sosial Kota Bekasi. 


\section{Metode Penelitian}

Adapun dalam segala proses mulai dari awal hingga akhir penelitian ini menggunakan pendekatan kualitatif dengan tipe penelitian deskriptif. Adapun jenis data yang digunakan sebagai bahan penulis dalam penelitian ini meliputi data primer yang dikumpulkan dari situasi aktual, atau data yang diambil ketika peristiwa tersebut terjadi sehingga dinamakan data primer (Silalahi, 2012:289). Atau dengan kata lain, data primer merupakan suatu data yang diperoleh secara langsung dan aktual dari sumbernya yang dapat melalui wawancara dan studi dokumen. Selain itu terdapat data sekunder yang merupakan suatu data yang dihasilkan berdasarkan pengumpulan data dari tangan kedua atau dari sumber-sumber lain yang telah tersedia sebelumnya.

Dalam penelitian ini penulis akan menggunakan wawancara semistruktur, dengan terlebih dahulu menyiapkan instrumen penelitian berupa pedoman wawancara yang memuat garis-garis besar permasalahan terkait kinerja pelaksanaan Program Pelayanan dan Rehabilitasi Kesejahteraan Sosial (PPRKS) di Dinas Sosial Kota Bekasi. Adapun teknik penentuan informan dalam penelitian yang dengan menggunakan teknik purposive sampling, yaitu merupakan suatu teknik pengambilan sampel yang dilakukan secara sengaja. Maksudnya, seorang informan tidak diambil secara acak atau random, akan tetapi ditentukan atau dipilih sendiri oleh peneliti yang bersangkutan atas rasionalisasi atau pertimbangan tertentu. Peneliti memilih informannya berdasarkan kriteria penilaian tertentu yaitu berdasarkan standarisasi peneliti yang telah ditetapkan sesuai dengan topik penelitian yang akan dilakukan. Sebagaimana tabel berikut ini:

Tabel 2.1

Sumber Data Primer

\begin{tabular}{|c|l|}
\hline No. & \multicolumn{1}{|c|}{ Sumber Data dan Informan } \\
\hline 1. & Kepala Bidang Rehabilitasi Sosial \\
\hline 2. & Kepala Sub Bagian Perencanaan \\
\hline 3. & Kepala Seksi Rehabilitasi Anak dan Lanjut Usia \\
\hline 4. & Kepala Seksi Penyuluhan Masyarakat \\
\hline 5. & Masyarakat/Penerima Program Pelayanan \\
\hline
\end{tabular}

Sumber: Sumber diolah peneliti (2019)

Adapun yang menjadi bahan-bahan untuk sumber sekunder yang akan digunakan dalam penelitian ini berasal dari artikel-artikel dalam surat kabar, dokumen-dokumen, majalah populer, buku atau telaah gambar, atau artikel-artikel yang ditemukan dalam jurnaljurnal ilmiah yang isinya mengevaluasi atau mengkritisi sesuatu penelitian original yang lain atau dengan kata lain isi tulisan tersebut memuat komentar atas kritik terhadap tulisan yang telah ada sebelumnya.

Adapun di dalam proses penelitian kali ini saya sebagai penulis akan menggunakan teknik analisis data sebagaimana yang dikemukakan oleh Miles dan Huberman (dalam Bungin, 2015:223) yang di dalamnya terdiri dari tiga alur kegiatan, diantaranya reduksi, penyajian data, dan penarikan kesimpulan. 


\section{Hasil Dan Pembahasan}

Berdasarkan hasil dari data hasil penelitian yang telah dilangsungkan pada penelitian ini yang didapatkan melalui metode wawancara mendalam yang dilakukan oleh peneliti mulai dari tanggal 22-29 Maret 2019. Kemudian dilakukan suatu wawancara mendalam terhadap seluruh informan yang terpilih menjadi sampel wawancara mendalam yang telah dipilih oleh peneliti, yaitu pegawai Dinas Sosial Kota Bekasi serta masyarakat Kota Bekasi.

Untuk mengetahui deskripsi hasil penelitian kinerja Pelaksanaan Program Pelayanan dan Rehabillitasi Kesejahteraan Sosial (PPKRS) di Dinas Sosial Kota Bekasi, peneliti menggunakan 6 (enam) indikator kinerja sebagaimana dikemukakan oleh Mahsun (2016:77) yaitu didasarkan atas tahapan mulai dari masukan (input), proses (process), eluaran (output), hasil (outcomes), manfaat (benefit), hingga dampak (impact) atas penelitian tersebut.

1. Kinerja Program Pelayanan dan Rehabilitasi Kesejahteraan Sosial berdasarkan tahapan Masukan (Input)

Tahapan masukan (input) merupakan suatu tahapan atas segala sesuatu yang dibutuhkan untuk menunjang kegiatan penelitian agar pelaksaaan kegiataan penelitian dapat berlangsung dan dapat pula menghasilkan keluaran (output) yang baik. Adapun yang menjadi indikator ialah dengan melakukan pengukuran atas jumlah sumber daya mulai dari anggaran (dana), sumber daya manusia (SDM), peralatan, material serta masukan lain yang dapat menunjang jalannya proses penelitian. Kemudian yang digunakan untuk melaksanakan program pelayanan dan rehabilitasi kesejahteraan sosial.

Menurut hasil pengamatan yang dilakukan, terlihat bahwa tidak terpcapainya targetan program pelayanan dan rehabilitasi kesejahteraan sosial dari segi masukan berupa minimnya anggaran yang disediakan. Adapun untuk tenaga kerja yang tersedia cukup memadai dimana tenaga kerja tersebut melibatkan beberapa aparatur sipil negara di lingkungan dinas sosial serta kelembagaan lainnya. Hal tersebut sejalan dengan ungkapan informan sebagai berikut:

"Sumber daya itu kan cukup mempergunakan tenaga yang ada dilingkungan dinas sosial, selama ini kalo ditinjau dari tenaga kerja cukup memadai. Nah namun kalo dilihat segi anggaran kurang memenuhi kebutuhan sehingga program ini kurang memenuhi target karena tidak terdistribusikan secara merata terhadap sasaran program." (Hasil wawancara dengan Kabid Rehabilitasi Sosial, tanggal 22 Maret 2019).

Minimnya anggaran yang disediakan untuk program pelayanan dan rehabilitasi kesejahteraan sosial di dinas sosial Kota Bekasi juga dipertegas oleh salah satu informan sebagai berikut:

"Analisa saya dari segi anggaran atau dana tidak mendukung dan targetan terlalu tinggi akhirnya tidak tercapai targetan yang telah ditentukan. Seharusnya kita menyesuaikan kebutuhan dalam menentukan anggaran nah disitu sering disebut sebagai rasionalisasi anggaran." (Hasil wawancara dengan Kabid Kasubag Perencanaan, tanggal 28 Maret 2019).

Namun disamping penyediaan anggaran yang minim dinas sosial juga masih kurang optimal dalam merealisasikan anggaran yang telah disediakan, sehingga masih banyak sasaran program yang belum menerima program pelayanan dan rehabilitasi kesejahteraan 
sosial. Berikut laporan keuangan dari program pelayanan dan rehabilitasi kesejahteraan sosial:

Tabel 3.1

Laporan Keuangan Program Pelayanan dan Rehabilitasi Kesejahteraan Sosial Kota Bekasi

\begin{tabular}{|c|c|}
\hline \multicolumn{2}{|c|}{ KEUANGAN } \\
\hline PAGU & REALISASI \\
\hline Rp. $533,137,800$ & Rp. $533,137,800$ \\
\hline Rp. $150,000,000$ & Rp. $138,320,000$ \\
\hline Rp. $150,000,000$ & Rp. $146,775,000$ \\
\hline $\mathbf{8 3 3 . 1 3 7 . 8 0 0}$ & $\mathbf{8 1 8 . 2 3 2 . 8 0 0}$ \\
\hline
\end{tabular}

Sumber: Diolah oleh peneliti dari Bidang Perencanaan Dinas Sosial Kota Bekasi Tahun 2017

Dari data yang telah disajikan di atas dapat analisa bahwa dinas sosial Kota Bekasi dinilai kurang optimal dalam merealisasikan anggaran pada program pelayanan dan rehabilitasi kesejahteraan sosial. Dinas Sosial Kota Bekasi dibentuk sebagai penyelenggara kebijakan dalam memberikan pelayanan terhadap Penyandang Masalah Kesejahteraan Sosial (PMKS) dengan tujuan untuk meningkatkan taraf kesejahteraan mereka. Hal ini sesuai dengan tugas pokok Dinas Sosial Kota Bekasi yang bertindak sebagai unsur pembantu dari walikota Bekasi sendiri dalam seluruh penyelenggaraan urusan pemerintahan di bidang sosial.

Program pelayanan dan rehabilitasi kesejahteraan sosial yang dilaksanakan oleh Dinas Sosial merupakan upaya untuk meningkatkan taraf kesejahteraan sosial. Profesionalitas sumber daya manusia merupakan salah satu indikator agar program pelayanan dan rehabilitasi kesejahteraan sosial berjalan optimal. Data tersebut didapat dari hasil wawancara sebagaimana yang diungkapkan oleh seorang informan perwakilan dari Dinas Sosial Kota Bekasi sebagai berikut:

"Disamping anggaran, kita juga masih membutuhkan sumber daya manusia yang profesional. Kita akui SDM professional kita masih sedikit sehingga ini menjadi pemicu tidak tercapainya targetan program terutama dalam kegiatan pelatihan memasak bagi pra lansia terlantar. Diadakannya program ini dimaksudkan agar menekan angka lansia terlantar yang berdaya di Kota Bekasi mas namun sekali lagi kita terbentur biaya dan tenaga yang profesional jadinya hanya diberikan sekali saja waktu itu” (Hasil wawancara dengan Kasi Rehabilitasi Anak dan Lanjut usia, tanggal 29 Maret 2019).

Pernyataan di atas menjelaskan bahwa tenaga profesional di lingkungan Dinas Sosial Kota Bekasi sangat diperlukan guna menunjang terlaksananya suatu program dan kegiatan. Hal tersebut dibuktikan bahwa dari 46 orang Aparatur Sipil Negara (ASN) yang ada di Dinas Sosial Kota Bekasi hanya 6 orang yang memiliki latar belakang pendidikan di bidang sosial. 
Dari uraian di atas bahwa hasil penelitian aspek kajian kinerja pelaksanaan program pelayanan dan rehabilitasi kesejahteraan sosial berdasarkan masukan (input) masih kurang baik. Hal ini dapat dilihat dari minimnya anggaran, kurang optimal dalam merealisasikan anggaran, dan tenaga kerja profesional yang masih sedikit. Sehingga menjadikan program tidak mencapai targetan yang telah ditentukan.

2. Kinerja Program Pelayanan dan Rehabilitasi Kesejahteraan Sosial berdasarkan Proses (Process)

Proses (Process) kinerja program pelayanan dan rehabilitasi kesejahteraan sosial adalah mengukur kegiatan yang ditinjau dari segi kecepatan serta akurasi dalam segala penyelenggaraan pelaksanaan kegiatan tersebut. Adapun ranah yang paling dominan di dalam proses adalah bergantung pada tingkat keefesiensian setiap organisasi dalam setiap pelaksanaan program atau kegiatannya. Efisiensi yang dimaksud dalam indicator dari proses sendiri menempatkan pada sasaran terhadap hasil dari perolehan jumlah pemanfaatan dari sejumlah masukan (input).

Untuk mencapai hasil yang besar dalam pelaksanaan program pelayanan dan rehabilitasi kesejahteraan sosial maka Dinas Sosial harus melaksanakan program tersebut dengan cepat dan akurat. Dalam hal ini Dinas Sosial bekerja sesuai dengan tugasnya masingmasing sesuai bidang, terutama pada bidang Rehabilitasi Sosial selaku pelaksana program. Dimana bidang Rehabilitasi Sosial memberikan pelayanan terhadap lanjut usia terlantar selaku sasaran program pelayanan dan rehabilitasi kesejahteraan sosial.

Jadi untuk mencapai kecepatan dan ketepatan dalam pelaksanaan program, Dinas Sosial melalui bidang Rehabilitasi Sosial bekerja sesuai tugas dan fungsinya masing-masing atau sesuai Standar Operasional Prosedur (SOP) yang ada. Melalui wawancara mendalam yang dilakukan oleh peneliti bahwa bidang Rehabilitasi Sosial telah melaksanakan program sesuai dengan tupoksi yang ada sebagaimana yang diungkapkan oleh salah satu informan sebagai berikut:

"Ya sesuai lah, kita melaksanakan program sesuai dengan kemampuan anggaran dan tujuan yang ada. Kita memberikan permakanan itu ala kadarnya ketika anggaran itu ada kita langsung memberikannya kepada yang berhak." (Hasil wawancara dengan Kabid Rehabilitasi Sosial, tanggal 22 Maret 2019).

Selain pelaksanaan yang dilakukan dengan cepat tanggap oleh Bidang Rehabilitasi Sosial, pelaksanaan program tersebut juga didukung oleh UPD lintas sektoral. Contohnya dalam pelaksanaan program ini didukung oleh pihak Satpol PP Kota Bekasi dalam mendistribusikan sembako untuk lansia terlantar. Seperti yang telah diungkapkan oleh informan perwakilan dari Bidang Kasubag Perencanaan Dinas Sosial Kota Bekasi sebagai berikut:

\footnotetext{
"Jadi gini, bahwa Dinas Sosial melakukan kegiatan atau program tidak mungkin berdiri sendiri. Kita harus bekerjasama dengan UPD lintas sektoral, seperti Satpol PP yang membantu atau berkontribusi dalam memberikan pemecahan persoalan yang menjadi target kinerja Dinas Sosial.” (Hasil wawancara dengan Kabid Kasubag Perencanaan, tanggal 28 Maret 2019).
} 
Melibatkan UPD lintas sektoral merupakan cara yang tepat, cepat, dan akurat dalam melaksanakan program atau kegiatan. program pelayanan dan rehabilitasi kesejahteraan sosial ini juga didukung oleh pihak Satpol PP Kota Bekasi. Hal ini dijelaskan oleh informan perwakilan dari Satpol PP Kota Bekasi sebagai berikut:

"Jadi untuk program Pelayanan dan Rehabilitasi Kesejahteraan Sosial yang dilaksanakan oleh Dinas Sosial Kota Bekasi kita bantu pada kegiatan pendistribusian sembako terhadap lansia terlantar dan yang tidak memiliki jaminan sosial. Nah, untuk ketaatan ASN dari pihak Dinsos dan Satpol PP sendiri alhamdulillah sangat semangat dan menjalankannya dengan penuh rasa tanggung jawab pada waktu itu." (Hasil wawancara dengan Kasi Bimbingan dan Penyuluhan Masyarakat, tanggal 02 April 2019).

Pernyataan di atas tentang ketaatan ASN yang terlibat dalam pelaksanaan program juga dipertegas oleh Kabid Reahabilitasi Kesejahteraan Sosial sebagai berikut:

"Kalo PNS antusias lah, bahkan mereka sangat tanggung jawab sekali dalam waktu pelaksanaan. Bahkan pengennya kita itu program ini menjadi rutinitas tiap bulannya." (Hasil wawancara dengan Kabid Rehabilitasi Sosial, tanggal 22 Maret 2019).

Dari ungkapan dan gambar di atas menyatakan bahwa keterlibatan pihak luar Dinas Sosial dan ketaatan para pelaksana program menjadikan program tersebut berjalan cepat dan akurat atau lebih efisien. Melibatkan pihak di luar jajaran Dinas Sosial merupakan suatu kemampuan intelektual dan ketaatan pelaksana program merupakan kemampuan fisik. Kemampuan ini adalah salah satu hal yang mempengaruhi kinerja, sebagaimana yang dijelaskan Robbins (2002: 50) kemampuan adalah suatu kapasitas untuk mengerjakan berbagai tugas dalam suatu pekerjaan. Kemampaun tersebut dapat dilihat dari dua segi: (1) Kemampuan intelektual, yaitu kemampuan yang diperlukan untuk melakukan kegiatan mental, dan (2) kemampuan fisik, yaitu kemampuan yang diperlukan untuk melakukan tugastugas menuntut stamina, cekatan, kekuatan, dan keterampilan.

Dari uraian di atas dapat dilihat bahwa aspek kajian kinerja pelaksanaan program Pelayanan dan Rehabilitasi Kesejahteraan Sosia berdasarkan proses (Process) secara umum baik. Hal tersebut dapat dilihat pada peran pelaksana yang saling bekerja sama dan ketaatan ASN dalam menjalankan tugas selama proses pelaksanaan program pelayanan dan rehabilitasi kesejahteraan sosial. Atas dasar tersebut, menjadikan program Pelayanan dan Rehabilitasi Kesejahteraan Sosial terlaksana secara cepat dan akurat atau efisien.

3. Kinerja Program Pelayanan dan Rehabilitasi Kesejahteraan Sosial berdasarkan Keluaran (Output)

Keluaran (output) didefinisikan sebagai suatu hal yang di tujukan langsung untuk segala sasaran dari seluruh pencapaian dari suatu kegiatan tertentu baik yang bentuknya berwujud maupun tidak berwujud. Keluaran yang dihasilkan oleh Dinas Sosial Kota Bekasi di Kota Bekasi dalam pelaksanaan program pelayanan dan rehabilitasi kesejahteraan sosial ialah terdiri dari bentuk fisik dan jasa atau pelayanan.

Analisis mengenai pembandingan antara keluaran mengenai apakah suatu kegiatan yang terlaksana dapat sesuai dengan rencana. Indikator dari segi keluaran ini dijadikan suatu pedoman penilaian untuk kemajuan dari suatu kegiatan yang dilaksanakan yang tolak 
ukurnya dikaitkan dengan sasaran kegiatan yang baik dan terukur. Oleh sebab itu, indikator dari segi keluaran ini harus dapat relevan dengan lingkup dan sifat dari kegiatan instansi, peneliti sendiri memaparkan bahwa yang menjadi bagian dari indikator dari keluaran sendiri meliputi seluruh bantuan sosial terhadap masyarakat.

Program pelayanan dan rehabilitasi kesejahteraan sosial merupakan pemberian bantuan berupa sembako dan pelatihan dari pemerintah daerah kepada lansia terlantar yang bersifat berjangka dan selektif. Hal ini ditujukan sebagai tindak antisipasi dan perlindungan terhadap kemungkinan terjadinya resiko sosial. Program ini memiliki beberapa kegiatan diataranya pemenuhan permakanan bagi lansia terlantar dan pelatihan memasak bagi lansia terlantar yang masih produktif.

Program pelayanan dan rehabilitasi kesejahteraan sosial disesuaikan dengan keuangan daerah atau kemampuan daerah serta dilakukan seselektif mungkin dan segala pemenuhan belanja terhadap urusan wajib seluruhnya telah ditetapkan dalam suatu peraturan perundangundangan yang berlaku. Pemberian sembako dan pelatihan terhadap lansia terlantar yang produktif sendiri bertujuan guna menunjang sasaran dari pencapaian terhadap program pemerintah daerah Kota Bekasi melalui Dinas Sosial Kota Bekasi dengan memperhatikan dan mempertimbangkan asas dan nilai dari segi keadilan, kepatutan, rasionalitas serta manfaat untuk masyarakat sendiri.

Berikut merupakan hasil wawancara peneliti dengan informan yang berada di lingkungan Dinas Sosial Kota Bekasi mengenai program pelayanan dan rehabilitasi kesejahteraan sosial yang diberikan terhadap lansia terlantar:

"Program ini ada beberapa kegiatan yaitu yang pertama, pemberian sembako dan pelatihan masak terhadap lansia terlantar secara selektif. Adapun komponen sembako yang kami berikan merupakan sembako pada umumnya seperti beras, minyak, gula dan lain-lain. Tentunya kami mengoptimalkan pemberian sembako dan pelatihan masak tersebut sesuai dengan sisi jumlah dan anggaran artinya kami hanya memberikan sembako tersebut sewaktu-waktu saja ketika anggaran itu ada kami jalankan." (Hasil wawancara dengan Kabid Rehabilitasi Sosial, tanggal 22 Maret 2019).

Berdasarkan penjelasan hasil wawancara di atas program pelayanan dan rehabilitasi kesejahteraan sosial yang diberikan kepada lansia terlantar berupa pemberian sembako dan pelatihan memasak disesuaikan dengan kemampuan anggaran yang dimiliki oleh pemerintah Kota Bekasi. Adapun program yang diberikan kepada lansia terlantar menjadi kurang maksimal sebab anggaran yang masih minim sebagaimana yang telah dijelaskan pada indikator masukan (input) sebelumnya.

Pernyataan di atas mengenai pemberian sembako berupa bahan pokok makanan serta pelatihan dipertegas oleh pernyataan salah satu informan penerima program pelayanan dan rehabilitasi kesejahteraan sosial sebagai berikut:

"Iya mas, waktu itu kita diberikan beberapa bahan makanan pokok kayak sembako gitu, isi sembakonya waktu kaya beras, minyak, gula, terigu pokoknya lengkap lah mas. Cumen waktu itu juga ada yang dikasih pelatihan masak mas saya juga diajarin cara buat lontong mas, waktu itu cumen ada 2 macem jenis makanan si mas lontong sama karedok." (Hasil Wawancara dengan perwakilan penerima program, tgl 27 Maret 2019). 
Berdasarkan hasil wawancara di atas menurut peneliti bantuan yang diberikan Dinas Sosial Kota Bekasi kepada masyarakat masih terkendala dana, dilihat dari masih kurangnya penerima program yang diberikan. Sebagaimana yang tertera dalam LAKIP bahwa target awal penerima program berjumlah 1.890 jiwa sedangkan yang terealisasi hanya 1.068 jiwa. Dilihat dari keluaran program pelayanan dan rehabilitasi kesejahteraan sosial para lansia terlantar telah menerima kegiatan secara menyeluruh, namun hal tersebut disesuaikan dengan anggaran dan kemampuan yang ada. Adapun daftar jumlah penerima program perkegiatan sebagai berikut:

Tabel 3.2

Jumlah Penerima Program Pelayanan dan Rehabilitasi Kesejahteraan Sosial

\begin{tabular}{|l|l|c|}
\hline \multicolumn{1}{|c|}{ Program } & \multicolumn{1}{|c|}{ Kegiatan } & Jumlah Penerima \\
\hline $\begin{array}{l}\text { Program Pelayanan dan } \\
\text { Rehabilitasi Kesejahteraan } \\
\text { Sosial }\end{array}$ & $\begin{array}{l}\text { Pemberian Sembako Kepada } \\
\text { Cacat Mental di Panti Sosial }\end{array}$ & 20 Orang \\
\cline { 2 - 3 } & $\begin{array}{l}\text { Pemberian Sembako dan } \\
\text { Pelatihan Kepada Lansia }\end{array}$ & 548 Orang \\
\cline { 2 - 3 } & $\begin{array}{l}\text { Penguatan Lembaga Lanjut } \\
\text { Usia Indonesia (LLI) }\end{array}$ & 500 Orang \\
\hline \multicolumn{2}{|c|}{ Total } & $\mathbf{1 . 0 6 8}$ Orang \\
\hline
\end{tabular}

(Sumber: Diolah oleh peneliti dari Bidang Perencanaan Dinas Sosial Kota Bekasi Tahun 2017)

Berdasarkan uraian di atas, kinerja pelaksanaan program pelayanan dan rehabilitasi kesejahteraan sosial yang ditinjau dari keluarannya (output) masih kurang baik. Hal tersebut dibuktikan bahwa beberapa kegiatan dapat dijalankan oleh Dinas Sosial Kota Bekasi dan tersampaikan pada sasaran program secara langsung. Namun jumlah penerima sasaran program tidak sesuai dengan target awal yang direncanakan, sebagaimana yang telah dipaparkan dalam LAKIP bahwa Dinas Sosial Menargetkan 1.890 jiwa sedangkan berdasarkan data yang ada penerima program hanya 1.068 jiwa.

4. Kinerja Program Pelayanan dan Rehabilitasi Kesejahteraan Sosial berdasarkan Hasil (Outcomes)

Hasil (Outcomes) didefinisikan sebagai segala sesuatu yang menjadi cerminan dari berjalannya serta berfungsinya keluaran dari kegiatan untuk jangka menengah. Segala macam pengukuran terhadap indikator ini seringkali menjadi tidak relevan dengan indikator yang dihasilkan oleh keluaran. Hasil yang menggambarkan tingkat pencapaian atau hasil yang lebih tinggi sehingga memungkinkan untuk mencakup seluruh kepentingan dari banyak pihak. Melalui indikator hasil organisasi maka akan dapat diketahui mengenai apakah hasil yang telah diperoleh dalam bentuk keluaran dapat digunakan serta diimplementasikan untuk kepentingan sebagaimana fungsinya dan apakah keluaran tersebut mampu memberikan kegunaan atau dampak positif yang besar untuk masyarakat luas.

Indikator dari hasil pelaksanaan program pelayanan dan rehabilitasi kesejahteraan sosial yaitu meliputi meningkatnya kerjasama antara Dinas Sosial Kota Bekasi dengan UPD lintas lokal salah satunya adalah SATPOL PP Kota Bekasi. Kemudian terpenuhinya kebutuhan lansia terlantar serta menjadikan lansia terlantar produktif lebih berdaya lagi dari sebelumnya. 
Meningkatnya kerjasama antara Dinas Sosial Kota Bekasi dengan UPD tingkat lokal dalam pelaksanaan program pelayanan dan rehabilitasi kesejahteraan sosial merupakan suatu bentuk usaha yang dilakukan bersama oleh antar kelompok yang emiliki tujuan yang sama guna mencapai tujuan bersama. Kerjasama menajdi hal yang urgent karena mencakup aspek interaksi yang paling penting karena pada hakikatnya manusia merupakan makhluk yang bersifat zoon politicon yang membuatnya tidak dapat hidup sendiri tanpa adanya bantuan dari orang lain seerta senantiasa menjadikannya sebagai makhluk yang selalu membutuhkan orang lain. Kerjasama sendiri dapat berlangsung ketika individu-individu yang bersangkutan memiliki tujuan yang sama serta memiliki keinginan untuk bekerja sama guna meealisasikan tujuan yang ingin mereka capai agar dapat tercapai.

Kerjasama merupakan suatu bentuk kinerja yang dilaksanakan oleh dua instansi atau lebih berdasarkan ketepatan dalam proses kegiatan tanpa ada kekeliruan dalam segala hal. Dalam hal ini yaitu kerjasama dengan Satpol PP Kota Bekasi dalam mendistribusikan sembako dimana dalam memberikan kinerja yang cepat dan tepat. Berikut hasil wawancara peneliti dengan informan mengenai kerjasama dalam pelaksanaan program pelayanan dan rehabilitasi kesejahteraan sosial:

"Kebetulan pihak dinsos bekerjasama dengan satpol pp sekaligus menjalin kordinasi dalam melaksanakan program pelayanan dan rehabilitasi kesejahteraan itu sendiri." (Hasil wawancara dengan Kabid Rehabilitasi Sosial, tanggal 22 Maret 2019).

Pernyataan di atas dipertegas oleh salah satu informan yang berhasil ditemui dan diwawancarai oleh peneliti, adapun hasil wawancara tersebut sebagai berikut:

"Jadi untuk program Pelayanan dan Rehabilitasi Kesejahteraan Sosial yang dilaksanakan oleh Dinas Sosial Kota Bekasi kita bantu pada kegiatan pendistribusian sembako terhadap lansia terlantar dan yang tidak memiliki jaminan sosial." (Hasil wawancara dengan Kasi Bimbingan dan Penyuluhan Masyarakat, tanggal 02 April 2019).

Berdasarkan penjelasan di atas Dinas Sosial Kota Bekasi sudah berjalan dengan baik dalam bekerjasama dengan instansi terkait. Hal tersebut dapat dilihat pada kerjasama anatara Dinas Sosial Kota Bekasi dengan Satpol PP Kota Bekasi dalam mendistribusikan sembako terhadap lansia terlantar. Meskipun pemberian sembako tidak memenuhi jumlah target awal namun Dinas Sosial telah memenuhi kebutuhan pokok lansia terlantar hingga jangka waktu tertentu. Berikut merupakan hasil wawancara dengan salah satu informan selaku penerima program pelayanan dan rehabilitasi kesejahteraan sosial:

"Kalo masalah sembako alhamdulillah mas kita merasa kebantu, kebutuhan pokok buat makan terpenuhi bahkan sampe satu bulan mas waktu itu. Cuman pengennya kita terus-terusan mas bukan cumen satu kali aja. Untung waktu itu saya juga diajari masak lontong sama karedok mas, jadi saya bisa cari duit lewat jualan lontong mas." (Hasil Wawancara dengan perwakilan penerima program, tgl 27 Maret 2019).

Pernyataan di atas menyatakan bahwa pemberian sembako mampu menunjang kebutuhan pokok dalam jangka waktu tertentu. Namun sasaran program berharap agar program tersebut berjalan terus-menerus agar dapat menunjang kebutuhan permakanan mereka. Adapun informan di atas merasa cukup terbantu dengan adanya pelatihan yang 
diberikan Dinas Sosial Kota Bekasi karena hal tersebut mampu menunjang perekonomiannya.

Pemantauan lebih lanjut sangat dibutuhkan perihal hasil (outcomes) dari pelaksanaan program pelayanan dan rehabilitasi kesejahteraan sosial menjadikan aspirasi sasaran dari program kurang terserap. Sehingga sasaran program berharap ada keberlanjutan dari program tersebut pada frekuensi tertentu. Hal tersebut juga senada dengan yang diungkapkan salah satu informan sebagai berikut:

"Untuk pemantauan lebih lanjut tidak ada karena pelaksana program itu dilaksanakan oleh dinsos sendiri. Adapun pemantauan jika dinsos menyerahkan kegiatan tersebut pada instansi lain. Kemudian untuk akses itu sendiri kepengennya kita kalo pemerintah daerah memiliki kemampuan lebih dari itu kita kepengennya mengintensifkan kesejahteraannya." (Hasil wawancara dengan Kabid Rehabilitasi Sosial, tanggal 22 Maret 2019).

Berdasarkan uraian di atas, hasil (Outcomes) dari pelaksanaan program pelayanan dan rehabilitasi kesejahteraan sosial secara umum baik. Meskipun tidak adanya pemantauan lebih lanjut setelah dilaksanakan program tersebut dan akses yang didapat oleh sasaran program hanya pada waktu itu saja. Program pelayanan dan rehabilitasi kesejahteraan sosial mampu menunjang kebutuhan pokok sasaran program dalam jangka waktu tertentu dan dari pihak instansi sendiri juga dapat bekerjasama dalam melaksanakan program tersebut dengan baik sehingga pelaksanaan program pelayanan dan rehabilitasi kesejahteraan sosial berjalan sesuai dengan rencana dan tujuan yang telah ditetapkan.

5. Kinerja Program Pelayanan dan Rehabilitasi Kesejahteraan Sosial berdasarkan Manfaat (Benefit)

Manfaat (Benefit) didefinisikan sebagai suatu hal yang berkaitan dengan tujuan akhir dari setiap pelaksanaan kegiatan yang didasarkan atas indikator manfaat yang diperoleh berdasarkan indikator hasil mengenai apakah hasil yang diperoleh tersebut memiliki kegunaan bagi masyarakat atau sebaliknya. Umumnya manfaat tersebut baru dapat terlihat setelah selang beberapa waktu kemudian, khususnya dalam jangka menengah dan jangka panjang. Indikator manfaat menunjukkan hal-hal yang diharapkan untuk dicapai bila keluaran dapat diselesaikan dan berfungsi dengan optimal.

Keluaran dari program pelayanan dan rehabilitasi kesejahteraan sosial memang tidak memenuhi target awal Dinas Sosial namun jika dikaji dari segi manfaat baik dari Dinas Sosial maupun sasaran program cukup memberikan manfaat. Hal itu bisa dilihat dari pernyataan informan mengenai kemampuan pelaksana program menjawab permasalahan lansia terlantar. Adapun pernyataan tersebut sebagai berikut:

"Kalo mengatasi masalah buat kebutuhan pokok mah mas Alhamdulillah terpenuhi waktu itu. Ya tadi mas kita mah pengennya tiap bulan atau berapa kali dalam setahun ada kegiatan pemberian sembako sama pelatihan lagi supaya kita yang masih kuat nyari duit ada keterampilan mas." (Hasil Wawancara dengan perwakilan penerima program, tgl 27 Maret 2019). 
Ungkapan di atas menjelaskan bahwa program pelayanan dan rehabilitasi kesejahteraan sosial mampu memberikan manfaat bagi sasaran program. Dimana bagi penerima sembako terpenuhi kebutuhan pokoknya dan bagi penerima program pelatihan menjadi berdaya dengan adanya keterampilan yang diberikan. Informasi di atas juga memperkuat penyataan salah satu informan yang mengatakan bahwa Dinas Sosial telah mengatasi permasalah bagi sasaran program. Berikut salah satu yang diungkapkan informan perwakilan dari Dinas Sosial:

"Tentunya kita menjalankan tugas sesuai permasalahan yang berkembang di Kota Bekasi dan adapun program ini untuk menjawab permasalah bagi lansia terlantar yang tidak mempunyai jaminan sosial sehingga mereka berhak mendapatkan bantuan berupa pelatihan bagi lansia produktif dan pemberian sembako bagi yang sudah tidak produktif." (Hasil wawancara dengan Kabid Rehabilitasi Sosial, tanggal 22 Maret 2019).

Pernyataan di atas memberikan penjelasan bahwa Dinas Sosial bekerja untuk menjawab permasalahan sasaran program. Kasubag Bidang perencanaan Dinas Sosial juga mengapresiasi atas kerja dari bidang rehabilitasi sosial sebagai berikut:

"Dinas Sosial dalam hal ini bidang rehabilitasi sosial tentunya sudah bekerja sesuai dengan permasalahan yang ada, terlebih kami sebagai perencana mengangkat suatu program berdasarkan permasalahan yang sedang berkembang di masyarakat sehingga kami berharap dengan adanya program yang kami sajikan mampu menjawab permasalahan yang ada." (Hasil wawancara dengan Kabid Kasubag Perencanaan, tanggal 28 Maret 2019).

Dari uraian di atas dapat diambil kesimpulan bahwa kinerja pelaksanaan program pelayanan dan rehabiltasi kesejahteraan sosial yang ditinjau dari manfaat (benefit) secara umum baik. Hal tersebut dapat terlihat pada kajian terpenuhinya kebutuhan sembako sasaran program dan keterampilan yang didapat oleh sasaran program sehingga sasaran program menjadi berdaya dalam jangka waktu tertentu. Keberhasilan dalam memberikan maanfaat tersebut didukung dari pihak Dinas Sosial yang mampu menganalisa permasalahan yang ada sehingga Dinas Sosial dapat mengatasi permasalahan tersebut.

6. Kinerja Program Pelayanan dan Rehabilitasi Kesejahteraan Sosial berdasarkan Dampak (Impact)

Dampak adalah pengaruh yang ditimbulkan baik positif maupun negatif. atau dampak yang memberikan gambaran terhadap dampak baik secara langsung atau tidak langsung yang dihasilkan berdasarkan pencapaian seluruh tujuan-tujuan program. Dampak merupakan outcome yang berada pada tingkatan yang lebih tinggi hingga batas tertentu, indikator kinerja dampak, mengukur outcome yang lebih makro dan melibatkan pihak lain diluar organisasi. Karena sifatnya yang tidak dikendalikan, maka indikator dampak boleh tidak disertai dengan target dari pencapaian, indikator dari dampak sendiri meliputi dampak yang bersifat positif serta yang bersifat negatif.

Dampak sendiri diartikan sebai suatu akibat, imbas atau pengaruh yang terjadi yang sifatnya dapat berwujud positif maupun negatif yang dihasilkan dari sebuah tindakan yang dilakukan oleh satu atau sekelompok orang yang melakukan kegiatan atau usaha tertentu. Kemudian kritik sendiri diartikan sebagai masalah untuk penganalisaan dan pengevaluasian 
terhadap suatu hal dengan tujuan peningkatan pemahaman, memperluas apresiasi serta membantu untuk memperbaiki pekerjaan. Karena kritik merupakan suatu tanggapan yang disertai dengan uraian dan pertimbangan yang rasional berdasarkan baik-buruknya sesuatu hal atau pendapat.

Faktor keberhasilan dalam program pelayanan dan rehabilatasi kesejahteraan sosial juga ditunjang oleh kritik dari berbagai pihak terutama pihak di luar instansi Dinas Sosial. Adanya masukan dari luar instansi tentang hal-hal yang dinilai masih minus dalam program pelayanan dan rehabilitasi kesejahteraan sosial dapat membantu dinas terkait dalam pengevaluasian serta perbaikan terhadap kekurangan yang ada. Kritik selalu disertai dengan saran karena pada dasarnya kritik merupakan uraian mengenai baik-buruknya sesuatu. Sedangkan saran diartikan sebagai sebuah solusi atau jalan keluar yang paling rasional yang ditunjukan untuk menyelesaikan permasalahan yang tengah dihadapi.

Saran harus bersifat membangun, mendidik, dan secara objektif sesuai topik yang dibahas. Faktor keberhasilan dalam program pelayanan dan rehabilitasi kesejahteraan sosial juga ditunjang oleh saran dari berbagai pihak. Adanya saran tentang hal-hal yang harus diperbaiki dalam program pelayanan dan rehabilitasi kesejahteraan sosial bisa dapat membantu dalam meningkatkan kinerja pelaksanaan program pelayanan dan rehabilitasi kesejahteraan sosial yang dilakukan oleh Dinas Sosial Kota Bekasi. Berikut merupakan hasil wawancara peneliti dengan aparatur Dinas Sosial Kota Bekasi, mengenai dampak dari program pelayanan dan rehabilitasi kesejahteraan sosial:

"Untuk dampak atau pengaruh dari diadakannya program pelayanan dan rehabilitasi kesejahteraan sosial ini yaitu banyaknya masukan untuk lebih memaksimalkan kinerja, seperti menambah anggaran dan profesionalitas pegawai agar program ini berjalan kontinu atau berkelanjutan dan tidak hanya sesekali saja." (Hasil wawancara dengan Kasi Bimbingan dan Penyuluhan Masyarakat, tanggal 02 April 2019).

Pernyataan sebagaimana yang telah dipaparkan di atas diperkuat dengan adanya salah satu informan selaku penerima program pelayanan dan rehabilitasi kesejahteraan sosial yang memberikan pernyataan sebagai berikut:

"Alhamdulillah mas kalo masalah pengaruh, buat saya pribadi cukup lah mas apalagi saya dapet pelatihan mas waktu itu jadi saya bisa ikut kerja di warung ibu lilis ini mas cumen buat sembako kalo bisa mah berkelanjutan mas jadi engga cumen waktu itu aja jadi buat lansia yang udah bener-bener tua ada jaminan buat makan sehari-harinya mas."'(Hasil Wawancara dengan perwakilan penerima program, tgl 27 Maret 2019).

Berdasarkan uraian dan hasil wawancara di atas dapat di Tarik suatu benag merah atau kesimpulan bahwa kinerja pelaksanaan program pelayanan dan rehabilitasi kesejahteraan sosial berdasarkan dampak (impact) secara umum baik. Dilihat dari pengaruh diadakannya program tersebut dapat memenuhi kebutuhan pokok sasaran program dan membuat sebagian sasaran program yang masih produktif menjadi berdaya. Meskipun program ini belum begitu maksimal dari sisi anggaran, namun sudah cukup optimal dalam memberikan dampak bagi sasaran program. 


\section{Simpulan}

Berdasarkan hasil analisis deskriptif dapat disimpulkan bahwa Dinas Sosial sudah memiliki kinerja yang cukup baik dalam pelaksanaan program pelayanan dan rehabilitasi kesejahteraan sosial. Hal ini dapat dilihat dari 4 indikator yang memiliki kategori optimal. Adapun 4 (empat) indikator tersebut yaitu:

1. Proses (Process), peran pelaksana yang saling bekerja sama dan ketaatan ASN dalam menjalankan tugas selama proses pelaksanaan program pelayanan dan rehabilitasi kesejahteraan sosial.

2. Hasil (Outcomes) terjalinnya kerjasama antara Dinas Sosial dengan UPD tingkat lokal Kota Bekasi.

3. Manfaat (Benefit), terpenuhinya bahan pokok permakanan bagi lansia yang sudah tidak produktif.

4. Dampak (Impact), keterampilan yang didapat oleh sasaran program sehingga sasaran program menjadi berdaya.

Adapun 2 (dua) indikator tersisa masuk dalam kategori kurang optimal. Berikut 2 (dua) indikator tersebut:

1. Masukan (Input), minimnya anggaran, kurang optimal dalam merealisasikan anggaran, dan tenaga kerja profesional yang masih sedikit.

2. Keluaran (output), sebagaimana yang tertera dalam LAKIP bahwa target awal penerima program berjumlah 1.890 jiwa sedangkan yang terealisasi hanya 1.068 jiwa.

\section{Referensi}

Adi, I.R. (2013). Kesejahteraan Sosial. Jakarta: Rajawali Pers.

Bungin, B.( 2015). Analisis Data Penelitian Kualitatif. Jakrata: PT Raja Gafindo Persada.

Dwiyanto, A. (2006). Mewujudkan Good Governance Melalui Pelayanan Publik. Yogyakarta: Gadjah Mada University Press.

Fahmi, Ilham. (2015). Manajemen Kinerja Teori dan Aplikasi. Bandung: Alfabeta.

Hardiyansyah. (2011). Kualitas Pelayanan Publik (Konsep, Dimensi, Indikator, dan Implementasinya). Yogyakarta: Gava Media.

Istianto, B. (2013). Demokratisasi Birokrasi. Jakarta: Mitra Wacana Media. LAN. (2009). Standar Pelayanan Publik. Jakarta: Lembaga Administrasi Negara (LAN).

Kiroim, B. (2015). Mengukur Kinerja pelayanan dan Kepuasan Konsumen (Edisi Revisi). Bandung: Pustaka Reka Cipta.

Mahsun, M. (2016). Pengukuran Kinerja Sektor Publik. Yogyakarta: BPFE-Yogyakarta.

Meleong, L.J. (2010). Metodologi Penelitian Kualitatif. Bandung: Remaja Rosdakarya.

Pasolong, H. (2014). Teori Administrasi Publik. Bandung: Alfabeta.

Rathod, P. B. (2010). Contemporary Public Administration. India: Abd Publisher.

Robbins, P. S. (2002). Perilaku Organisasi. Jakarta: Prenhalindo. 
Sedarmayanti. (2014). Manajemen Sumber Daya Manusia, Reformasi Birokrasi, dan Manajemen Negeri Sipil. Bandung: PT Refika Aditama.

Umam, K. (2010). Perilaku Organisasi. Bandung: CV. Pustaka Setia.

Umam, K. (2012). Manajemen Organisasi. Bandung: CV. Pusataka Setia.

Wibowo. (2016). Manajemen Kinerja. Edisi Kelima. Jakarta: PT Raja Grafindo Persada. 